\title{
Body and Muscle Growth of Pre-Larvae and Larvae of Turbot, Scophthalmus Maximus L., Reared at Three Different Temperatures
}

\author{
María Dolores Ayala ${ }^{1}$, María Jesús Lago² ${ }^{2}$ Rosa Cal${ }^{2}$ \\ ${ }^{1}$ Departamento de Anatomía y Anatomía Patológica Comparadas, Facultad de Veterinaria, Universidad de \\ Murcia, Murcia, Spain \\ ${ }^{2}$ Instituto Español de Oceanografía (IEO), Centro Oceanográfico de Vigo, Subida a Radio Faro, Vigo, Spain \\ Email: ${ }^{\text {mdayala@um.es }}$
}

Received 8 July 2015; accepted 21 September 2015; published 24 September 2015

Copyright (C) 2015 by authors and Scientific Research Publishing Inc.

This work is licensed under the Creative Commons Attribution International License (CC BY). http://creativecommons.org/licenses/by/4.0/

(c) (i) Open Access

\section{Abstract}

Three turbot groups were kept at $15^{\circ} \mathrm{C}-16^{\circ} \mathrm{C}$ (Cold Temperature, $\mathrm{T}$ ), $17^{\circ} \mathrm{C}-18^{\circ} \mathrm{C}$ (ambient $\mathrm{T}$ ) and $21^{\circ} \mathrm{C}-22^{\circ} \mathrm{C}$ (warm $\mathrm{T}$ ) during the larval development in order to study the thermal influence on muscle growth and larval development in this species. During the early stages (2 - 6 days of posthatching), the body and the muscle growth was scarce, although the hyperplasia increased slightly, being higher at ambient and at cold $T$ than at warm $T$. In contrast, the highest value of hypertrophy was found in the warm group. At 15 days of age, the body length and muscle growth increased in all the groups, being significantly higher in the warm than in the rest of groups. Thus, the highest values of both the hypertrophy and the hyperplasia of the white muscle fibres were reached at warm $T$, although it was only significant for the hyperplasia. The end of the metamorphosis was reached at 29 days of age in the warm group, whereas in the rest of groups it was no observed yet. At this developmental stage, the warm group showed the typical morphological mosaic of the myotome, and it was accompanied by an increase of the transverse area of the white and the red muscles, parallel to an increase of both the hypertrophy and the hyperplasia of the muscle fibres. The hyperplasia of the white fibres was the parameter most significantly increased. Also, the body length increased significantly in this group, reaching $\approx 1.6 \mathrm{~cm}$ at this stage.

\section{Keywords}

Growth, Development, Temperature, Muscle Fibres

${ }^{*}$ Corresponding author.

How to cite this paper: Ayala, M.D., Lago, M.J. and Cal, R. (2015) Body and Muscle Growth of Pre-Larvae and Larvae of Turbot, Scophthalmus Maximus L., Reared at Three Different Temperatures. Open Journal of Animal Sciences, 5, $402-410$. http://dx.doi.org/10.4236/ojas.2015.54042 


\section{Introduction}

Muscle growth involves the recruitment (hyperplasia) and subsequent increase in size (hypertrophy) of muscle fibres [1]. After hatching, the larval stage is an important period in which the intensity and/or alternation of hypertrophy and hyperplasia vary depending on several aspects such as the characteristics of each species, food and interrelation of external factors such as temperature, photoperiod, etc. [2]. This leads to a large intra- and inter-variability in the mechanism of growth of fishes. In red sea bream Pagrus major [3], the number of white fibers remained constant during the pre-larval phase, but the hypertrophy increased gradually. Similarly, at the beginning of the larval stage of herring, Clupea harengus [4]-[6], turbot, Scophthalmus maximus (L.) [7] and salmon Salmo salar [8], the white muscle grew by hypertrophy of existing fibers. However, in another salmon stock, other authors found a great generation of fibers in this period [9].

Temperature has a profound effect on the development and growth of fish [10] [11]. Thus, various studies show that the temperature accelerates myogenesis and development of organs and tissues of embryos and larvae of different teleost species such as salmon [8] [12] [13], herring [4] [5] [14] [15], plaice (Pleuronectes platessa L.) [16] and sea bass, Dicentrarchus labrax [2] [17]-[20]. The thermal effect on the axial musculature depends on various factors such as species, stage of growth, genetic factors, etc. [2]. Thus, in newly hatched larvae of herring, high incubation temperatures increased the white muscle hyperplasia [5] [14]. In newly hatched larvae of plaice, other authors observed that both hypertrophy and hyperplasia of the white fibers were increased at high incubation temperatures [16]. In salmon [8] [12] [13], turbot [7] and another stock of herring [4], the high incubation temperature increased the hypertrophy of the white muscle fibers.

Turbot is a marine teleost which is characterized by its rapid growth, reaching $1.85 \mathrm{~kg}$ at an age of $25-29$ months old. In aquaculture, high temperatures are applied in order to increase the growth rates. Some authors reared turbot larvae at different temperatures and observed that the developmental rate was faster at $18^{\circ} \mathrm{C}$ and $22^{\circ} \mathrm{C}$ than at $14^{\circ} \mathrm{C}$ [21]. Thus, the cold larvae showed a reduction in the rate of ossification and growth in comparison with the larvae reared at higher $\mathrm{T}$. Recent studies revealed in this species that the thermal early history influenced in the juvenile and adult stages [22]. Hence, the thermal effect is important in the larval specimens in order to elucidate the mechanisms that influence their growth in short and long terms. The present work studies the mechanisms of muscle growth in turbot larvae being maintained at different Ts. The results can be useful to optimize the rearing conditions during the larval stages.

\section{Material and Methods}

\subsection{Fish Samples and Rearing Conditions}

This experiment was carried out with turbot specimens proceeding of a stock of spawners adapted to captivity at the Instituto Español de Oceanografía (Centro Oceanográfico de Vigo, España). All the methods being used in the present work are in accordance with the European Directive (2010/63/EU) for the protection of animals used for scientific purposes and in accordance with the current legislation in Spain (RD 53/2013, of February 1), which establishes the basic rules for the protection of animals used for experimental and other scientific purposes. Turbot embryos were obtained in October of 2013. The embryo period lasted 5 days at $14^{\circ} \mathrm{C}-15^{\circ} \mathrm{C}$. At 2 days posthatching (dph) the larvae were divided into three groups in duplicate 450-L tanks (density: 30 larvae $\mathrm{L}^{-1}$ ) which were maintained at $15^{\circ} \mathrm{C}-16^{\circ} \mathrm{C}$ (cold group: $\mathrm{C}$ ), $17^{\circ} \mathrm{C}-18^{\circ} \mathrm{C}$ (ambient group: A) and $21^{\circ} \mathrm{C}-22^{\circ} \mathrm{C}$ (warm group: $\mathrm{W}$ ), respectively until the end of the experiment. These temperatures (Ts) cover the range of larval $\mathrm{T}$ that this species can encounter in the natural environmental [21]. At 3 dph the larvae opened the mouth. At this moment all fish were fed ad libitum with rotifers until $7 \mathrm{dph}$. From 8 to $10 \mathrm{dph}$, the larvae were fed with rotifers plus Artemia sp. nauplii. From 10 to $17 \mathrm{dph}$ the larvae were fed with newly hatched Artemia sp. nauplii, and from 17 - 29 days they were fed with multigain ${ }^{R}$ enriched-Artemia metanauplii. The experiment finished at $30 \mathrm{dph}$. Muscle samples were obtained during the following stages post-hatching: 2 days (common $\mathrm{T}$ in all the larvae: $14^{\circ} \mathrm{C}-15^{\circ} \mathrm{C}$ ) 6 days ( 3 thermal groups: $\mathrm{C}, \mathrm{A}$ and $\mathrm{W}$ ), 15 days ( 3 thermal groups: $\mathrm{C}, \mathrm{A}$ and $\mathrm{W}$ ) and 29 days (only in the $\mathrm{W}$ group, coinciding with the end of the larval metamorphosis in this group at $1.4-1.8 \mathrm{~cm}$ of body length). At each stage, 20 turbots per group (10/tank) were transported in bags with oxygen to the Veterinary Faculty of Murcia.

\subsection{Muscle Samples Processing for Structural Studies}

In Veterinary Faculty of Murcia, the larvae were killed by an overdose of the anesthetic MS-222. Later on, the 
specimens were fixed in 2.5\% glutaraldehyde in buffered $0.1 \mathrm{M}$ cacodylate $(\mathrm{pH} 7.2-7.4)$ for $3 \mathrm{~h}$ at $4^{\circ} \mathrm{C}$ and then embedded in Epon resin according to other authors [23]. Subsequently, the specimens were cut transversely along the long body axis from the point of the anal opening. Further processing was performed in the Servicio Universitario de Microscopía Electrónica (University of Murcia, Spain), according to the standard protocol for epoxy embedding. Semi-thin sections ( $5 \mu \mathrm{m}$ thick) were obtained with a Reichert Jung (Heidelberg, Germany) ultramicrotome and then stained with Toluidine Blue.Muscle growth was quantified in 10 specimens per group (5/tank) by means of a morphometric analysis system (Sygma Scan Pro5). The following parameters were measured: total cross-sectional area of the red and white muscles, number of red and white muscle fibres, size (area and minor axis length) of red and white muscle fibres and muscle fibre density (number of fibres $/ \mu \mathrm{m}^{2}$ ). In early larvae $(2-6 \mathrm{dph})$, most of the muscle fibres were measured in the whole section of the myotome. In the rest of the stages (15 and $29 \mathrm{dph}$ ), due to the large number of muscle fibres, the average size was estimated from the fibres located in the intermediate and apical sectors in one half of the transversal section of the myotome, following the methodology described by other authors [24]. Body length was measured in all specimens (20/ group).

\subsection{Statistical Analysis}

The statistical analysis was performed with Statistical Package SPSS 15.0. The mean and standard error (SEM) were calculated in each group. Data distribution was analyzed in each stage by the Shapiro-Wilk test for $P<$ 0.05. Data showed a normal distribution $(P>0.05)$. Analysis of variance (ANOVA) was used to evaluate the temperature effect at each sampling point, for $P<0.05$. Tukey test was used to compare means as post-hoc analysis.

\section{Results}

\subsection{Endogenous Phase (from the Fertilization until the End of the Yolk Phase)}

Embryo phase lasted 5 days at $14^{\circ} \mathrm{C}-15^{\circ} \mathrm{C}$. The specimens were kept to this $\mathrm{T}$ until $2 \mathrm{dph}$. At this age $(2 \mathrm{dph})$ mean body length was $2.7 \mathrm{~mm}( \pm 0.2)$ (Table 1$)$. The mouth opening and the reabsorption of the yolk sac took place at 3 and at $4 \mathrm{dph}$, respectively.

At 2 dph the transverse section of the myotome of the pre-larvae showed two muscular strata just behind the anal opening: a superficial monolayer of red muscle fibres and a deeper stratum of white muscle fibres. Red muscle fibres had high mitochondrial content and scarce myofibrillar content (Figure 1(a)). Beneath the red fibres, there were several layers of polygonal white fibres, with few mitochondria and abundant myofibrils. The myofibrils were still incomplete and the position of the nuclei was usually central.

\subsection{Days Post-Hatching}

At 6 dph, a few small fibres were observed adjacent to the horizontal septum, which corresponded to precursors of new red muscle fibres (Figure 1(b)). The degree of maturity of the white fibres was slightly higher than in the previous stage. When comparing the different thermal groups, we observed the incipient beginning of the stratified hyperplasia at the dorsal and ventral extremes of the myotome in both the ambient and the cold groups (Figure 1(b)), whereas in the warm group it was not observed.

The body length and the transverse area of the white and the red muscles did not grow significantly. However, the number of fibres increased slightly. In relation to the thermal effect, the body length and the transverse area of the white muscle were greater at cold and at ambient $\mathrm{T}$ than at warm $\mathrm{T}$ (Table 1). The size of the white and the red muscle fibres were greater at warm $\mathrm{T}$, followed by cold $\mathrm{T}$, showing the ambient group the smallest size (Table 1 and Table 2). The number of fibres showed the inverse tendency, such that the highest number was found at ambient $\mathrm{T}$, followed by the cold $\mathrm{T}$, showing the warm group the smallest values (Table 1 and Table 2).

\subsection{Days Post-Hatching}

New white muscle fibres appeared at the epaxial and hypaxial extremes (the second phase of myogenesis) in all the specimens, although it was more evident in the warm group (Figure 1(c) and Figure 1(d)). The red muscle presented a higher degree of development than in the previous stages, mainly in the warm group. The pink o in- 
termediate layer of the myotome was already present in the warm group (not shown). Also, in this latter groupsome small fibres could already be observed among the adult white fibres, thus indicating the incipient mosaic phase (the third phase of myogenesis). When comparing the growth in this stage in relation to the previ-

Table 1. Body length and white muscle parameters (Mean \pm SEM) in the three thermal groups: cold (C), ambient (A) and warm (W) groups) during the vitelline and larval phases. Different superscripts indicate significant differences $(P<0.05)$ among light regimes within each stage.

\begin{tabular}{|c|c|c|c|c|c|}
\hline & & 2 days & 6 days & 15 days & 29 days \\
\hline \multirow{3}{*}{ Total length (mm) } & $\mathrm{C}$ & & $3.3^{\mathrm{a}} \pm 0.1$ & $4.1^{\mathrm{a}} \pm 0.2$ & \\
\hline & A & $2.7 \pm 0.2$ & $3.3^{\mathrm{a}} \pm 0.1$ & $4.3^{\mathrm{a}} \pm 0.2$ & \\
\hline & $\mathrm{W}$ & & $2.6^{\mathrm{b}} \pm 0.3$ & $8.2^{\mathrm{b}} \pm 0.5$ & $16.3 \pm 0.5$ \\
\hline \multirow{4}{*}{ White muscle transverse section $\left(\mu \mathrm{m}^{2}\right)$} & $\mathrm{C}$ & & $18,378.1^{\mathrm{a}} \pm 1862$ & $62,316.7^{\mathrm{a}} \pm 7998.8$ & \\
\hline & A & $11,537.9 \pm 361.7$ & $16,796.9^{\mathrm{a}} \pm 526.4$ & $89,854.6^{\mathrm{a}} \pm 11,643.2$ & \\
\hline & $\mathrm{W}$ & & $16,026.6^{\mathrm{a}} \pm 5184.9$ & $228,606.2^{\mathrm{b}} \pm 59,462.4$ & $830,757.7 \pm 143,863.9$ \\
\hline & $\mathrm{C}$ & & $79.7^{\mathrm{a}} \pm 3.6$ & $83.2^{\mathrm{a}} \pm 4.8$ & \\
\hline \multirow{6}{*}{ White muscle fibres minor axis length $(\mu \mathrm{m})$} & A & $61.4 \pm 4.3$ & $60.9^{\mathrm{b}} \pm 3.2$ & $82.6^{\mathrm{a}} \pm 4.2$ & \\
\hline & $\mathrm{W}$ & & $87.9^{\mathrm{a}} \pm 9.5$ & $90.6^{\mathrm{a}} \pm 4.1$ & $156.2 \pm 26.8$ \\
\hline & $\mathrm{C}$ & & $7.5^{\mathrm{a}} \pm 0.2$ & $7.2^{\mathrm{a}} \pm 0.2$ & \\
\hline & $\mathrm{A}$ & $7.1 \pm 0.2$ & $6.2^{\mathrm{b}} \pm 0.2$ & $7.4^{\mathrm{a}} \pm 0.2$ & \\
\hline & $\mathrm{W}$ & & $7.8^{\mathrm{a}} \pm 0.4$ & $7.5^{\mathrm{a}} \pm 0.2$ & $10.7 \pm 0.9$ \\
\hline & $\mathrm{C}$ & & $229.6^{\mathrm{a}} \pm 23.8$ & $745.9^{\mathrm{a}} \pm 67.4$ & \\
\hline \multirow[t]{3}{*}{ Number of white muscle fibres } & $\mathrm{A}$ & $190.2 \pm 9.3$ & $300.5^{\mathrm{a}} \pm 43.3$ & $1086.3^{\mathrm{a}} \pm 96.5$ & \\
\hline & $\mathrm{W}$ & & $194.1^{\mathrm{a}} \pm 39.9$ & $2505.2^{\mathrm{b}} \pm 550.5$ & $5796.7 \pm 965.2$ \\
\hline & $\mathrm{C}$ & & $131.3^{\mathrm{a}} \pm 16.7$ & $123.7^{\mathrm{a}} \pm 9.6$ & \\
\hline \multirow{2}{*}{$\begin{array}{l}\text { White muscle fibres density } \\
(\times 10,000)\left(\text { number } / \mu \mathrm{m}^{2}\right)\end{array}$} & $\mathrm{A}$ & $165.8 \pm 10.8$ & $179.6^{a} \pm 26.4$ & $125.2^{\mathrm{a}} \pm 12.7$ & \\
\hline & $\mathrm{W}$ & & $159.3^{\mathrm{a}} \pm 59$ & $120.2^{\mathrm{a}} \pm 12.8$ & $71.9 \pm 12.0$ \\
\hline
\end{tabular}

Table 2. Red muscle parameters (Mean \pm SEM) in the three thermal groups: cold (C), ambient (A) and warm (W) groups) during the vitelline and larval phases. Different superscripts indicate significant differences $(P<0.05)$ among light regimes within each stage.

\begin{tabular}{|c|c|c|c|c|c|}
\hline & & 2 days & 6 days & 15 days & 29 days \\
\hline \multirow{4}{*}{ Red muscle transverse section $\left(\mu \mathrm{m}^{2}\right)$} & $\mathrm{C}$ & & $1967.4^{\mathrm{a}} \pm 231.1$ & $8093.1^{\mathrm{a}} \pm 839.4$ & \multirow{4}{*}{$63,081.1 \pm 14,939.3$} \\
\hline & A & $2204.7 \pm 113.4$ & $1911.3^{\mathrm{a}} \pm 145.4$ & $12,582.6^{a} \pm 1968.7$ & \\
\hline & $\mathrm{W}$ & & $2457.8^{a} \pm 986.4$ & $25,476.6^{\mathrm{b}} \pm 6280.4$ & \\
\hline & $\mathrm{C}$ & & $13.6^{\mathrm{a}} \pm 1.7$ & $34.3^{\mathrm{a}} \pm 4.8$ & \\
\hline \multirow[t]{3}{*}{ Red muscle fibres area $\left(\mu \mathrm{m}^{2}\right)$} & A & $21.3 \pm 0.9$ & $11.9^{\mathrm{a}} \pm 0.8$ & $45.6^{\mathrm{b}} \pm 6.8$ & \multirow{3}{*}{$78.9 \pm 12.0$} \\
\hline & $\mathrm{W}$ & & $30.6^{\mathrm{b}} \pm 8.7$ & $40.0 \mathrm{a} \pm 9.5$ & \\
\hline & $\mathrm{C}$ & & $3.3^{\mathrm{a}} \pm 0.2$ & $5.9^{\mathrm{a}} \pm 0.4$ & \\
\hline \multirow[t]{3}{*}{ Red muscle fibres minor axis length $(\mu \mathrm{m})$} & A & $4.5 \pm 0.1$ & $3.2^{\mathrm{a}} \pm 0.2$ & $6.6^{\mathrm{b}} \pm 0.6$ & \\
\hline & W & & $4.9^{\mathrm{b}} \pm 1.8$ & $5.5^{\mathrm{a}} \pm 0.7$ & $7.8 \pm 0.8$ \\
\hline & $\mathrm{C}$ & & $155.9^{\mathrm{a}} \pm 18.6$ & $243.4^{\mathrm{a}} \pm 22.8$ & \multirow{5}{*}{$886.5 \pm 217.7$} \\
\hline \multirow[t]{3}{*}{ Number of red muscle fibres } & A & $100.2 \pm 6.8$ & $167.8^{\mathrm{a}} \pm 13.7$ & $274.1^{\mathrm{a}} \pm 14.8$ & \\
\hline & W & & $106.2 \mathrm{a} \pm 21.1$ & $764.8^{\mathrm{b}} \pm 222.1$ & \\
\hline & $\mathrm{C}$ & & $820.1^{\mathrm{a}} \pm 102.4$ & $311.4^{\mathrm{a}} \pm 36.3$ & \\
\hline \multirow{2}{*}{$\begin{array}{l}\text { Red muscle fibres density } \\
(\times 10,000)\left(\text { number } / \mu \mathrm{m}^{2}\right)\end{array}$} & A & $470.6 \pm 20.6$ & $852.2^{\mathrm{a}} \pm 54.8$ & $248.7^{\mathrm{a}} \pm 51.5$ & \\
\hline & $\mathrm{W}$ & & $684.7^{\mathrm{a}} \pm 332.3$ & $264.8^{\mathrm{a}} \pm 62.8$ & $146.2 \pm 33.2$ \\
\hline
\end{tabular}



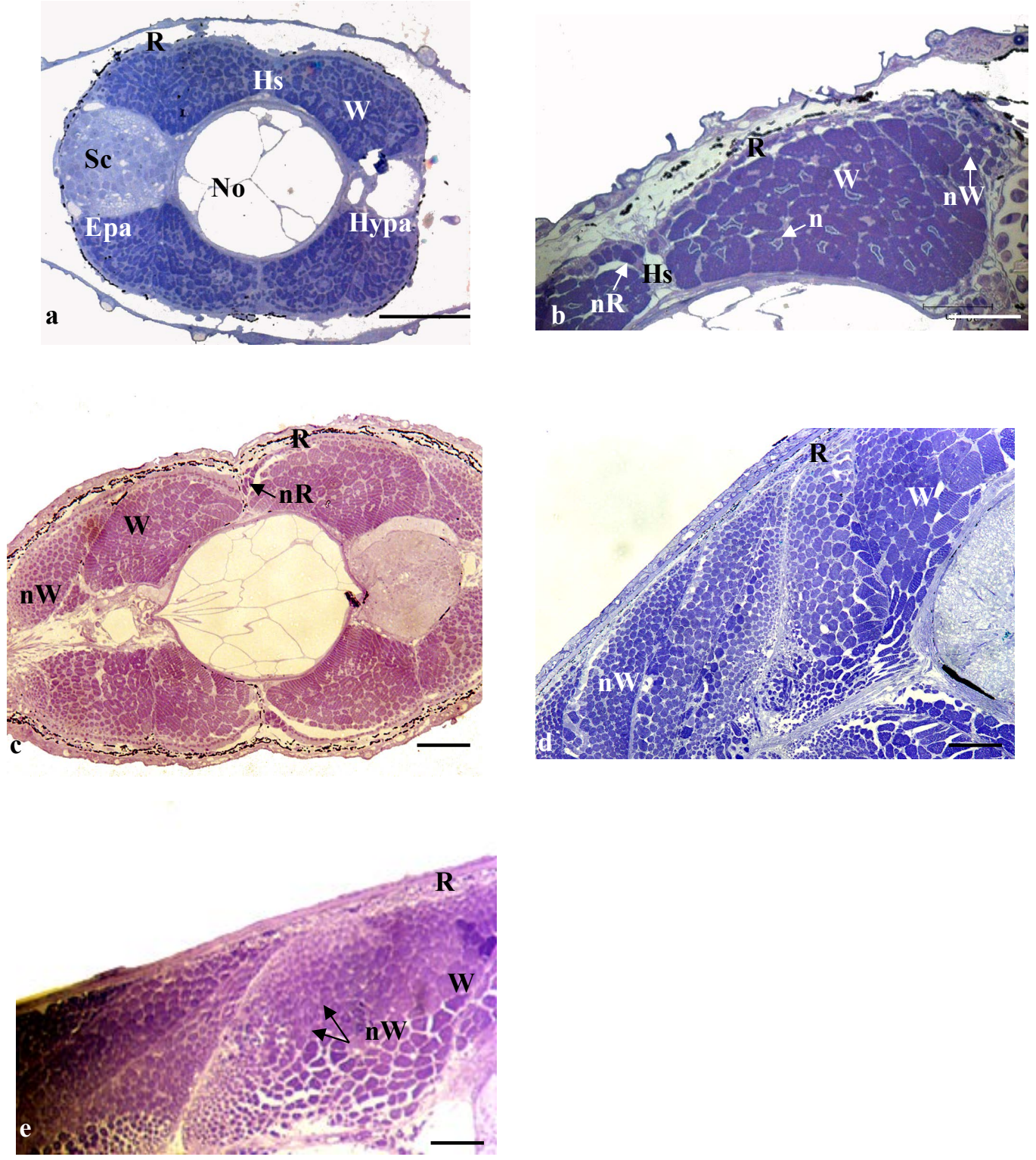

Figure 1. Transverse muscle sections stained with Toluidine blue from 2 days old specimens of the ambient group (a) 6 days old specimens of the cold group (b), 15 days old specimens of the cold (c) and of the warm groups (d) and 29 days old specimens of the warm group (e). Bar: a, (c)-(d): $50 \mu \mathrm{m}$; (b): $20 \mu \mathrm{m}$. R: red muscle fibres; nR: new red fibres; hs: horizontal septum; No: notochord; Sc: spinal cord; Epa: epaxial extreme of the myotome; Hypa: hypaxial extreme of the myotome, N: nucleus of white myotube, $\mathrm{W}$ : white muscle fibres; $\mathrm{nW}$ : new white muscle fibres.

ous stages, it was observed a significant increasing of the body length in all the groups. Also, the transverse area of the white and the red muscles increased in all the groups, parallel to an increase of the hyperplasia of red and white fibers.

In relation to the thermal influence, the body length and all the white muscle parameters were greater at warm $\mathrm{T}$ than in the rest of groups (Table 1). However, these results were only significant for the number of white fibres. The red muscle showed a similar tendency to than described for the white muscle, with the only exception of the size of the red fibres, which showed the highest value at ambient $\mathrm{T}$ (Table 2).

\subsection{Days Post-Hatching}

At this stage, the warm group completed the metamorphosis, such that the migration of eyes was completed and 
the spines and the swim bladder were fully reabsorbed. Also, the swimming behaviours changed. Thus, whereas in the previous stages the larvae swam on the surface of the tanks, in this stage the specimens already swam on the bottom of the tank, showing the adult behavioural performance.

The mean body length was $16.3 \mathrm{~mm}( \pm 0.5)$. In relation to the myotome, the morphological mosaic was already evident in the red and white muscles of all the specimens of this group (third phase of myogenesis) (Figure 1(e)). The rest of groups had not completed the metamorphosis yet and hence, we did not collect samples from these groups.

When comparing the growth in the warm group in relation to the previous stages, it was observed an significant increasing of the body length and the transverse area of the white and the red muscles (Table 1 and Table 2). Hypertrophy and hyperplasia of the red and white muscle fibres were also observed, but it was only significant for the hyperplasia of the white fibres.

\section{Discussion}

\subsection{Muscle and Body Growth}

Eggs and pre-larvae were kept at $14^{\circ} \mathrm{C}-15^{\circ} \mathrm{C}$ from the fertilization to the end of the vitelline phase. Embryo phase lasted 5 days, which coincided with the results found in other populations of this species under these thermal conditions [7] [25]. 2 days after hatching the mean body length was $2.7 \mathrm{~mm}$ and the yolk sac was still present. The thermal conditions being used in this endogenous phase are considered optimal for yolk utilization [21] [26] [27]. The mouth opening and the reabsorption of the vitelline sac took place at 3 and at $4 \mathrm{dph}$, respectively. Other authors [27] found similar results described in the present work. Thus, newly hatched larvae measured $\sim 2.3-2.8 \mathrm{~mm}$, the reabsorption of the vitelline yolk took place at $3-4 \mathrm{dph}$ and the mouth opening happened at $4-6 \mathrm{dph}$ [27]. According to these authors the main processes occurring during the endogenous stage are the absorption of the yolk and its conversion into body tissue. At the end of this stage, these authors observed that the gills were open, the eyes were black, the mouth and anus were open, and the gut was ready to receive food. In other flatfish this phase in larval development is considerably longer, lasting $\sim 10-12$ days in Lepidopsetta mochigarei and Xystrias grigorjewi [28] [29] and 12 - 14 days in plaice [30] [31].

In relation to the muscle structure, a superficial monolayer of red muscle fibres and immature white muscle fibres were observed, coinciding with those observed in this species [7] and other teleosts: gilthead sea bream, Sparus aurata [32], dentex, Dentex dentex [33] [34] and sea bass [18]-[20] and shi drum, Umbrina cirrosa [24]. During this phase, muscle growth was scarce, corresponding with an endogenous feeding period, where the development interacted with the muscle growth [2] [27] [35].

At $6 \mathrm{dph}$, an apparent hyperplasia of white and red fibers was observed, whereas the hypertrophy was not observed. In contrast, other authors observed an increasing of hypertrophy in turbot pre-larvae [7]. This shows the intra-specific variations that exist in fish, as observed in other teleosts. Thus, in a stock of salmon, other authors found that the muscle growth was largely due to hypertrophy during the endogenous phase [8]. In contrast, other authors observed a great generation of new fibres during this early period [9].

At 15 - $29 \mathrm{dph}$, turbots of the present work increased both the hypertrophy and the hyperplasia, but it was more significant for the hyperplasia. This coincides with that found previously in this species [7] and other teleosts such as salmon [9], sea bass [2] [19] and shi drum [24], and shows that the hyperplasia is the main mechanism involved in fast growth.

\subsection{Thermal Effect on Muscle and Body Growth}

In relation to the thermal influence, it was observed that at 6 days post-hatching, the specimens previously maintained at cold and ambient $\mathrm{T}$ reached higher values of body length, transverse area of the white muscle and number of fibres than the specimens reared at warm T. In contrast, the warm group showed higher values of hypertrophy than the rest of groups. However, these results were not always significant. Similarly, other authors observed greater hypertrophy in newly hatched larvae of turbot previously incubated at higher embryonic temperatures [7]. Also, newly hatched larvae of $S$. salar previously incubated at high T showed higher hypertrophy but lower hyperplasia than larvae previous incubated at lower T [8] [12] [13]. These results demonstrate that the temperature seems to have a different effect on cell division (hyperplasia) that on protein synthesis (hypertrophy) [12]. 
At 15 days post-hatching, the body length and the muscle growth showed higher values at warm $\mathrm{T}$ than in the rest of groups, mainly due to the significant increase of the hyperplasia of the white fibres in the warm group, where the secondary myogenesis or stratified hyperplasia was more evident than in the rest of groups. Similarly, other authors found higher values of hyperplasia in 26 days old larvae of turbot reared at $16^{\circ} \mathrm{C}$ than at $12^{\circ} \mathrm{C}$ [7]. Also, other teleosts have shown greater growth at higher rearing temperature, being the hyperplasia the muscle parameter most significantly influenced, that is consistent with the general finding that in fish rapid growth is associated with muscle fibre hyperplasia [9] [17]-[19]. Other authors reared turbot larvae under similar conditions than those described in the present study [21]. They found significant differences in the wet body mass from 15 days on, such that the ambient $\left(18^{\circ} \mathrm{C}\right)$ and the warm groups $\left(22^{\circ} \mathrm{C}\right)$ grew faster than the cold group $\left(14^{\circ} \mathrm{C}\right)$.

Other authors [36] reared Senegalese sole larvae, Solea solea at $15^{\circ} \mathrm{C}, 18^{\circ} \mathrm{C}$ or $21^{\circ} \mathrm{C}$ during the pelagic phase. During pre-metamorphosis and metamorphosis, larvae from $21^{\circ} \mathrm{C}$ weighed more than those reared at $18^{\circ} \mathrm{C}$ or $15^{\circ} \mathrm{C}$ and it was concomitant with an increase in gene expression, namely myogenic regulatory factors. Also, larvae of gilthead sea bream, Sparus aurata L. were reared at different temperatures to metamorphosis and it resulted in a greater body mass at higher temperature [37].

In the present work, the larval metamorphosis was completed earlier at higher $\mathrm{T}$, such that the warm group finished this development stage at 29 days post-hatching, whereas the rest of groups had not completed the metamorphosis yet at this age. Thus, at 29 days, the morphological mosaic (the third phase of myogenesis) was already observed in the warm group, parallel to a significant increase of the hyperplasia of the white fibers. Similarly, other authors observed that the larval period was shorter at $16^{\circ} \mathrm{C}$ than at $12^{\circ} \mathrm{C}$ in turbot [7]. These authors observed that the development of the gut, the swim bladder and the caudal fin took place earlier at higher T, which could be associated with an increase in digestion efficiency and in buoyancy in the water column. These changes in the relative timing of organogenesis could promote growth and survival at higher temperatures [7]. Similar changes in the relative time of development have also been observed in this species by other authors [21]. These authors observed that at $50 \mathrm{dph}$, larvae from the warm and the ambient groups showed the same developmental stage as those reared at cold $\mathrm{T}$ at $80 \mathrm{dph}$. Turbot reared at cold $\mathrm{T}$ showed a reduction in the rate of ossification and growth [21]. The positive effect of the temperature on the developmental rate has also been observed in other teleosts [8] [12] [14] [15] [17]-[19] [36]. On the other hand, in some teleosts (halibut Hippoglossus hippoglossus [38]; salmon [6] [39] [40]; sea bass [17] [18] [20]; European pearlfish Rutilus meidingeri Heckel [41]; Senegalese sole [36]; gilthead sea bream [37]) has also been shown that early T determines future growth characteristics. In this sense, we have carried out a recent study with three groups of turbot reared under the same conditions than in the present work until $150 \mathrm{dph}$ and then transferring all of them to ambient $\mathrm{T}$ until the commercial size [22]. Results showed lasting $\mathrm{T}$ effects on the subsequent muscle growth, such that it seems that the early $\mathrm{T}$ produce imprinting effects on the muscle myogenic precursors as suggested by different authors [41] [42]. Hence, we think that the application of different Ts in the fish farming should consider the thermal influence in both short and long terms to optimize the final performance.

\section{Acknowledgements}

This work has been conducted through a partnership between Vigo Oceanographic Institute and University of Murcia.

\section{References}

[1] Weatherley, A.H., Gill, H.S. and Lobo, A.F. (1988) Recruitment and Maximal Diameter of Axial Muscle Fibres in Teleosts and Their Relationship to Somatic Growth and Ultimate Size. Journal of Fish Biology, 33, 851-859. http://dx.doi.org/10.1111/j.1095-8649.1988.tb05532.x

[2] Ayala, M.D., López-Albors, O., Gil, F., Abellán, E., García-Alcázar, A., Abdel, I. and Latorre, R. (2005) Revisión: Influencia de la temperatura sobre el desarrollo y crecimiento muscular de la lubina, Dicentrarchus labrax L. Anales de Veterinaria de Murcia, 21, 55-68.

[3] Matsuoka, M. (1984) Morphometry of the Myotomal Muscle Fibres in Larvae and Juveniles of the Red Sea Bream. Bulletin of the Japanese Society for the Science of Fish, 50, 1811-1816. http://dx.doi.org/10.2331/suisan.50.1811

[4] Johnston, I.A. (1993) Temperature Influences Muscle Differentiation and the Relative Timing of Organogenesis in Herring (Clupea harengus) Larvae. Marine Biology, 116, 363-379. http://dx.doi.org/10.1007/BF00350053 
[5] Johnston, I.A., Vieira, V.L.A. and Abercromby, M. (1995) Temperature and Myogenesis in Embryos of the Atlantic Herring Clupea harengus. Journal of Experimental Biology, 198, 1389-1403.

[6] Johnston, I.A., Cole, N.J., Abercromby, M. and Vieira, V.L.A. (1998) Embryonic Temperature Modulates Muscle Growth Characteristics in Larval and Juvenile Herring. Journal of Experimental Biology, 201, 623-646.

[7] Gibson, S. and Johnston, I.A. (1995) Temperature and Development in Larvae of the Turbot Scophthalmus maximus. Marine Biology, 124, 17-25. http://dx.doi.org/10.1007/BF00349142

[8] Nathanailides, C., López-Albors, O. and Stickland, N.C. (1995) Influence of Prehatch Temperature on the Development of Muscle Cellularity in Posthatch Atlantic-Salmon (Salmo salar, L.). Canadian Journal of Fish and Aquatic Science, 52, 675-680. http://dx.doi.org/10.1139/f95-068

[9] Johnston, I.A. and Mclay, H.A. (1997) Temperature and Family Effects on Muscle Cellularity at Hatch and First Feeding in Atlantic Salmon (Salmo salar L.). Canadian Journal of Zoology, 75, 64-74. http://dx.doi.org/10.1139/z97-008

[10] Herzig, A. and Winkler, H. (1986) The Influence of Temperature on the Embryonic Development of Three Cyprinid Fishes, Aramis brama, Chalcalburnus chalcoides mento and Vimba vimba. Journal of Fish Biology, 28, 171-181. http://dx.doi.org/10.1111/j.1095-8649.1986.tb05155.x

[11] Blaxter, J.H.S. (1988) Pattern and Variety in Development. In: Hoar, W.S. and Randall, D.J., Eds., Fish Physiology, Volume XIA, Academic Press, New York, 1-58. http://dx.doi.org/10.1016/s1546-5098(08)60198-3

[12] Stickland, N.C., White, R.N., Mescall, P.E., Crook, A.R. and Thorpe, J.E. (1988) The Effect of Temperature on Myogenesis in Embryonic Development of the Atlantic Salmon (Salmo salar, L.). Anatomy and Embryology, 178, 253-257. http://dx.doi.org/10.1007/BF00318228

[13] Usher, M.L, Stickland, N.C. and Thorpe, J.E. (1994) Muscle Development in Atlantic Salmon (Salmo salar) Embryos and the Effect of Temperature on Muscle Cellularity. Journal of Fish Biology, 44, 953-964. http://dx.doi.org/10.1111/j.1095-8649.1994.tb01267.x

[14] Vieira, V.L.A. and Johnston, I.A. (1992) Influence of Temperature on Muscle-Fibre Development in Larvae of the Herring Clupea harengus. Marine Biology, 112, 333-341. http://dx.doi.org/10.1007/BF00702480

[15] Johnston, I.A., Cole, N.J., Vieira, V.L.A. and Davidson, I. (1997) Temperature and Developmental Plasticity of Muscle Phenotype in Herring Larvae. Journal of Experimental Biology, 200, 849-868.

[16] Brooks, S. and Johnston, I.A. (1993) Influence of Development and Rearing Temperature on the Distribution, Ultrastructure and Myosin Subunit Composition of Myotomal Muscle Fibre Types in the Plaice Pleuronectes platessa. Marine Biology, 117, 501-513.

[17] Ayala, M.D., López-Albors, O., Gil, F., Latorre, R., Vázquez, J.M., García-Alcázar, A., Abellán, E., Ramírez, G. and Moreno, F. (2000) Temperature Effects on Muscle Growth of the Axial Musculature of the Sea Bass (Dicentrarchus labrax L.). Anatomia, Histologia, Embryologia, 29, 235-241. http://dx.doi.org/10.1046/j.1439-0264.2000.00262.x

[18] Ayala, M.D., López-Albors, O., Gil, F., García-Alcázar, A., Abellán, E., Alarcón, J.M., Álvarez, M.C., Ramírez-Zarzosa, G. and Moreno, F. (2001) Temperature Effects on Muscle Growth in Two Populations (Atlantic and Mediterranean) of Sea Bass, Dicentrachus labrax L. Aquaculture, 202, 359-370. http://dx.doi.org/10.1016/S0044-8486(01)00785-2

[19] Ayala, M.D., López-Albors, O., García-Alcázar, A., Abellán, E., Latorre, R., Vázquez, J.M., Ramírez Zarzosa, G., Martínez, F. and Gil, F. (2003) Effect of Two Thermal Regimes on the Muscle Growth Dynamics of Sea Bass Larvae, Dicentrarchus labrax L. Anatomia, Histologia, Embryologia, 32, 271-275. http://dx.doi.org/10.1046/j.1439-0264.2003.00482.x

[20] López-Albors, O., Ayala, M.D., Gil, F., García-Alcázar, A., Abellán, E., Latorre, R., Ramírez-Zarzosa, G. and Vázquez, J.M. (2003) Early Temperature Effects on Muscle Growth Dynamics and Histochemical Profile of Muscle Fibres of Sea Bass Dicentrarchus labrax L., during Larval and Juvenile Stages. Aquaculture, 220, 385-406. http://dx.doi.org/10.1016/S0044-8486(02)00532-X

[21] Torres-Núñez, E., Cal, R. and Rotllant, J. (2014) Phenotypic Plasticity during Early Ontogeny in Cultured Turbot (Scophthalmus maximus): Changes in Dorsal and Anal Fin Ray Counts by Water Temperature. Journal of Applied Ichthyology, 30, 762-766. http://dx.doi.org/10.1111/jai.12535

[22] Ayala, M.D., Gómez, C., Santaella, M. and Cal, R. (2014) Lasting Temperature Effects on the Muscle Tissue, Body Growth and Fillet Texture of Adult Turbots, Scophthalmus maximus, L. Proceedings of the Aquaculture European Congress, San Sebastián, Spain, 14-17 October 2014, 94-95.

[23] Wanson, J.C. and Drochman, P. (1968) Epoxi Technique Inclusion for Electron Microscopy. Cell Biology, 38, $130-150$. http://dx.doi.org/10.1083/jcb.38.1.130

[24] Ayala, M.D., Abellán, E., Arizcun, M., García-Alcázar, A., Navarro, F., Blanco, A. and López-Albors, O. (2013) Muscle Development and Body Growth in Larvae and Early Post-Larvae of Shi Drum, Umbrina cirrosa L., Reared under Different Larval Photoperiod: Muscle Structural and Ultrastructural Study. Fish Physiology and Biochemistry, 39, 807- 
827. http://dx.doi.org/10.1007/s10695-012-9742-x

[25] Iglesias, J., Rodríguez-Ojea, G. and Peleteiro, J.B. (1995) Effect of Light and Temperature on the Development of Turbot Eggs (Scophthalmus maximus L.). Proceedings of the ICES Marine Science Symposium, 201, 40-44.

[26] Jones, A. (1972) Studies on Egg Development and Larval Rearing of Turbot, Scophthalmus maximus L., and Brill, Scophthalmus rhombus L., in the Laboratory. Journal of the Marine Biological Association of the United Kingdom, 52, 965-986. http://dx.doi.org/10.1017/S0025315400040698

[27] Al-Maghazachi, S.J. and Gibson, R. (1984) The Developmental Stages of Larval Turbot, Scophthalmus maximus (L.). Journal of Experimental Marine Biology and Ecology, 82, 35-51. http://dx.doi.org/10.1016/0022-0981(84)90137-0

[28] Yusa, T. (1958) Eggs and Larvae of Flatfishes in the Coastal Waters of Hokkaido. III. Post-Embryonic Development and Larvae of the Flatfish Lepidopsetta mochigarei Snyder. Bulletin of Hokkaido Regional Fish Research Laboratory, 18, $1-10$.

[29] Yusa, T. (1961) Eggs and Larvae of Flatfishes in the Coastal Waters of Hokkaido. V. Embryonic Development of the Flatfish, Xystrias grigorjewi (Herzenstein). Bulletin of Hokkaido Regional Fish Research Laboratory, 19, 109-118.

[30] Fullarton, J.H. (1891) On the Development of the Plaice (Pleuronectes platessa). 9th Annual Report of Fisheries Board of Scotland, 311-316.

[31] Ryland, J.S. (1966) Observations on the Development of Larvae of the Plaice, Pleuronectes platessa L., in Aquaria. ICES Journal of Marine Science, 30, 177-195. http://dx.doi.org/10.1093/icesjms/30.2.177

[32] Patruno, M.G., Radaelli, G., Mascarello, F. and Candia Carnevali, M.D. (1998) Muscle Growth in Response to Changing Demands of Functions in the Teleost Sparus aurata (L.) during Development from Hatching to Juvenile. Anatomy and Embryology, 198, 487-504. http://dx.doi.org/10.1007/s004290050199

[33] Arizcun, M., López-Albors, O., García Alcázar, A., Orenes, M., Vázquez, J.M. and Abellán, E. (2005) Crecimiento del músculo blanco en larvas y postlarvas de dentón Dentex dentex L. Resúmenes del X Congreso Nacional de Acuicultura, Gandía.

[34] López-Albors, O., Arizcun, M., Abellán, E., Blanco, A., Ayala, M.D., Pastor, L.M. and Latorre, R. (2010) Posthatch Development of the Axial Musculature of the Common Dentex Dentex dentex, L (Teleostei). Histology and Histopathology, 25, 1557-1571.

[35] Kamler, E. (1992) Early Life History of Fish: An Energetics Approach. Chapman and Hall, London, 267 p. http://dx.doi.org/10.1007/978-94-011-2324-2

[36] Campos, C., Fernandes, J.M.O., Conceição, L.E.C., Engrola, S., Vousa, V. and Valente, L.M.P. (2013) Thermal Conditions during Larval Pelagic Phase Influence Subsequent Somatic Growth of Senegaleses Sole by Modulating Gene Expression and Muscle Growth Dynamics. Aquaculture, 414-415, 46-55. http://dx.doi.org/10.1016/j.aquaculture.2013.07.039

[37] García de la Serrana, D., Vieira, V.L.A., Andree, K.B., Darias, M., Estévez, A., Gisbert, E. and Johnston, I.A. (2012) Development Temperature Has Persistent Effects on Muscle Growth Responses in Gilthead Sea Bream. PLoS ONE, 7, 1-11. http://dx.doi.org/10.1371/journal.pone.0051884

[38] Galloway, T.F., Kjorsvik, E. and Kryvi, H. (1999) Muscle Growth in Yolk-Sac Larvae of the Atlantic Halibut as Influenced by Temperature in the Egg and Yolk-Sac Stage. Journal of Fish Biology, 55, 26-43. http://dx.doi.org/10.1111/j.1095-8649.1999.tb01044.x

[39] Johnston, I.A., Mclay, H.A., Abercromby, M. and Robbins, D. (2000) Early Thermal Experience Has Different Effects on Growth and Muscle Fibre Recruitment in Spring- and Autumn-Running Atlantic Salmon Populations. Journal of Experimental Biology, 203, 2553-2564.

[40] Johnston, I.A., Mclay, H.A., Abercromby, M. and Robbins, D. (2000) Phenotypic Plasticity of Early Myogenesis and Satellite Cell Numbers in Atlantic Salmon Spawning in Upland an Lowland Tributaries of a River System. Journal of Experimental Biology, 203, 2539-2552.

[41] Steinbacher, P., Marschallinger, J., Obermayer, A., Neuhofer, A., Sänger, A.M. and Stoiber, W. (2011) TemperatureDependent Modification of Muscle Precursor Cell Behaviour Is an Underlying Reason of Lasting Effects on Muscle Cellularity and Body Growth of Teleost Fish. Journal of Experimental Biology, 214, 1791-1801. http://dx.doi.org/10.1242/jeb.050096

[42] Johnston, I.A., Bower, N.I. and Macqueen, D.J. (2011) Growth and the Regulation of Myotomal Muscle Mass in Teleost Fish. Journal of Experimental Biology, 214, 1617-1628. http://dx.doi.org/10.1242/jeb.038620 